\title{
The larval development of the partner shrimp Periclimenes sagittifer (Norman, 1861) (Decapoda: Caridea: Palaemonidae: Pontoniinae) described from laboratory-reared material, with a note on chemical settlement cues
}

Received: 30 September 2003 / Revised: 31 March 2004 / Accepted: 14 April 2004 / Published online: 26 May 2004 (C) Springer-Verlag and AWI 2004

\begin{abstract}
The complete larval development (eight zoeae and megalopa) of Periclimenes sagittifer (Norman, 1861) (Decapoda: Palaemonidae: Pontoniinae) from laboratoryreared material is described and illustrated. The morphology of the first larval stage is compared with previous larval descriptions of other species in the genus (P. agag, $P$. americanus, $P$. calmani, $P$. diversipes, $P$. grandis and $P$. pandionis). The importance of chemical settlement cues for late stage Periclimenes larvae is discussed.
\end{abstract}

Keywords Periclimenes sagittifer - Larval development . Decapoda $\cdot$ Settlement cues

\section{Introduction}

In the northeast Atlantic and Mediterranean Sea, Periclimenes O.G. Costa, 1844 is represented by at least ten different species (see d'Udekem d'Acoz 1999). However, $P$. aegylios Grippa \& d'Udekem d'Acoz, 1996 and $P$. sagittifer (Norman, 1861) can only be clearly diagnosed by the coloration patterns of live specimens. According to Grippa and d'Udekem d'Acoz (1996) both species are believed to form the sagittifer complex, with $P$. aegylios being restricted to the Mediterranean and $P$. sagittifer occurring in Atlantic waters. Such differentiation between Atlantic and Mediterranean populations has already been discussed for the brachyuran genus Maja (Neumann 1998) and the caridean Hippolyte (Garcia-Raso et al.

Communicated by H.-D. Franke

\footnotetext{
A. dos Santos $(\square) \cdot$ C. Bartilotti

Instituto Nacional de Investigaçăo Agrária e das Pescas, IPIMAR, Av. de Brasília, s/n. 1449-006 Lisbon, Portugal

e-mail: antonina@ipimar.pt

Tel.: +351-2130-27000

Fax: $+351-2130-15948$

R. Calado $\cdot$ L. Narciso

Laboratório Marítimo da Guia, IMAR,

Estrada do Guincho, 2750-642 Cascais, Portugal
}

1998), with the different populations being recognized as separate species due to the absence of intermediate forms.

Notwithstanding the already puzzling systematic situation of the amethysteus group (Grippa and d'Udekem d'Acoz 1996), the existence of $P$. sagittifer specimens presenting abnormal coloration patterns (d'Udekem d'Acoz 1999) only increases the need for a major molecular study complemented by the comparison of adult and larval morphology.

Regarding the larval phase, there is still a great lack of knowledge concerning the complete larval development of any of the Periclimenes species occurring in this region (see González-Gordillo et al. 2001), since all the existing studies deal with larvae collected from plankton, e.g. Kurian (1956), Bourdillon-Casanova (1960), and dos Santos (1999). Gurney (1938) described five larval forms under the name Mesocaris, stating that they would be accepted without difficulties as Periclimenes. In fact, Kurian (1956) described, under the name Mesocaris, larvae that he thought were similar to the "Palaemonid B.R. V" described by Gurney (1938), which were recognised by Bourdillon-Casanova (1960) as larvae of the genus Periclimenes, when she described a larval sequence from plankton samples attributed to Periclimenes scriptus. Paula (1982) reported Periclimenes sp. larvae that have minor differences compared to the one described by Bourdillon-Casanova. Finally, dos Santos (1999) also described the third zoeal stage of a Periclimenes sp. found off Portuguese waters, which she classified according to Bourdillon-Casanova larval type.

More recently, the species of the Periclimenes genus have received special attention worldwide due to their demand as ornamental species in the multimillion-dollar marine aquarium industry (Calado et al. 2003a). Periclimenes sagittifer is one of the species presenting a strong potential for the aquarium industry (Calado et al. 2003b). Although the culture of marine ornamentals has been recommended in order to minimize the impacts of wild specimen collection (Corbin 2001), the absence of a 
complete larval description for this genus is one of the bottlenecks still impairing this approach. Additionally, the lack of knowledge regarding the importance of chemical cues of host species and conspecifics of symbiotic decapods on larval settlement (Goy 1990) is also a constraint to the development of suitable culture methodologies.

The aims of the present paper are to describe the complete larval development of $P$. sagittifer, to compare the larvae with those already described for the genus and to perform a preliminary evaluation of the importance of chemical cues in larval settlement of this symbiotic shrimp.

\section{Methods}

Periclimenes sagittifer ovigerous shrimps were collected in their host anemone Anemonia sulcata at Sagres, Portugal, during April 2001 by scuba divers. The females were kept in darkness until hatching, at $35 \mathrm{psu}$ salinity, $22^{\circ} \mathrm{C}$, with moderate aeration in a 1801 tank connected to a larval collector without their host anemone. The most active larvae were selected and 3,500 were stocked in a 2001 cylindrical-conical tank of a recirculated commercial-scale rearing system for decapod crustaceans (Calado et al. 2003c). Seawater was $1 \mu \mathrm{m}$-filtered, salinity was maintained at $35 \pm 1 \mathrm{psu}$ and temperature was kept at $22 \pm 1{ }^{\circ} \mathrm{C}$ by a heating/cooling system. The tank was illuminated from above with fluorescent light with an intensity of $1,000 \mathrm{~lx}$ at the water surface and a photoperiod LD 14:10. Twenty randomly selected larvae were sampled daily and staged to determine stage duration. Twenty days after moulting to the last zoeal stage, ten randomly chosen larvae were placed in a small mesh basket in a 70-1 tank stocked with three adult females of this species and three host anemones, Anemonia sulcata. Additionally, another ten randomly chosen larvae were placed in small individual plastic containers $(20 \mathrm{ml}$ each) with freshly cut tentacle tips (approximately $10 \mathrm{~mm}$ long) of their host anemone. All larval stages were fed daily on Artemia franciscana (Kellogg, 1906) metanauplii, enriched in Algamac 2000 at a density of 5,000 metanauplii $1^{-1}$.

The sampled larvae were fixed in $4 \%$ formaldehyde. Drawings and measurements were made with the aid of a camera lucida on a binocular Wild M8. Setal observations and drawings were made using a Zeiss microscope with a camera lucida. The preparation of slides with appendages was made with Faure's liquid (see Reyne 1949). Larval description followed the method proposed by Clark et al. (1998). The long aesthetascs on the antennules and the long plumose setae on distal exopod segments are drawn truncated, setal counts refer to the proximal to distal sequence. Measurements taken were distance between tip of rostrum and posterior end of telson (TL) and carapace length from tip of rostrum to posterior margin of carapace (CL). The spent females and complete larval series have been deposited in the Instituto Nacional de Investigaçăo Agrária e Pescas, IPIMAR in Lisbon, Portugal (number IPIMAR/P/Ps/ 06.2002)

\section{Results}

Eight zoeal and one megalopal stage were recognised. The first and last larval stages are completely described, while only the main differences of the other larval stages are described in detail.

\section{Rearing data}

All larvae in the last zoeal stage kept in the mass-rearing tank died 32 days after moulting to zoea VIII, with none

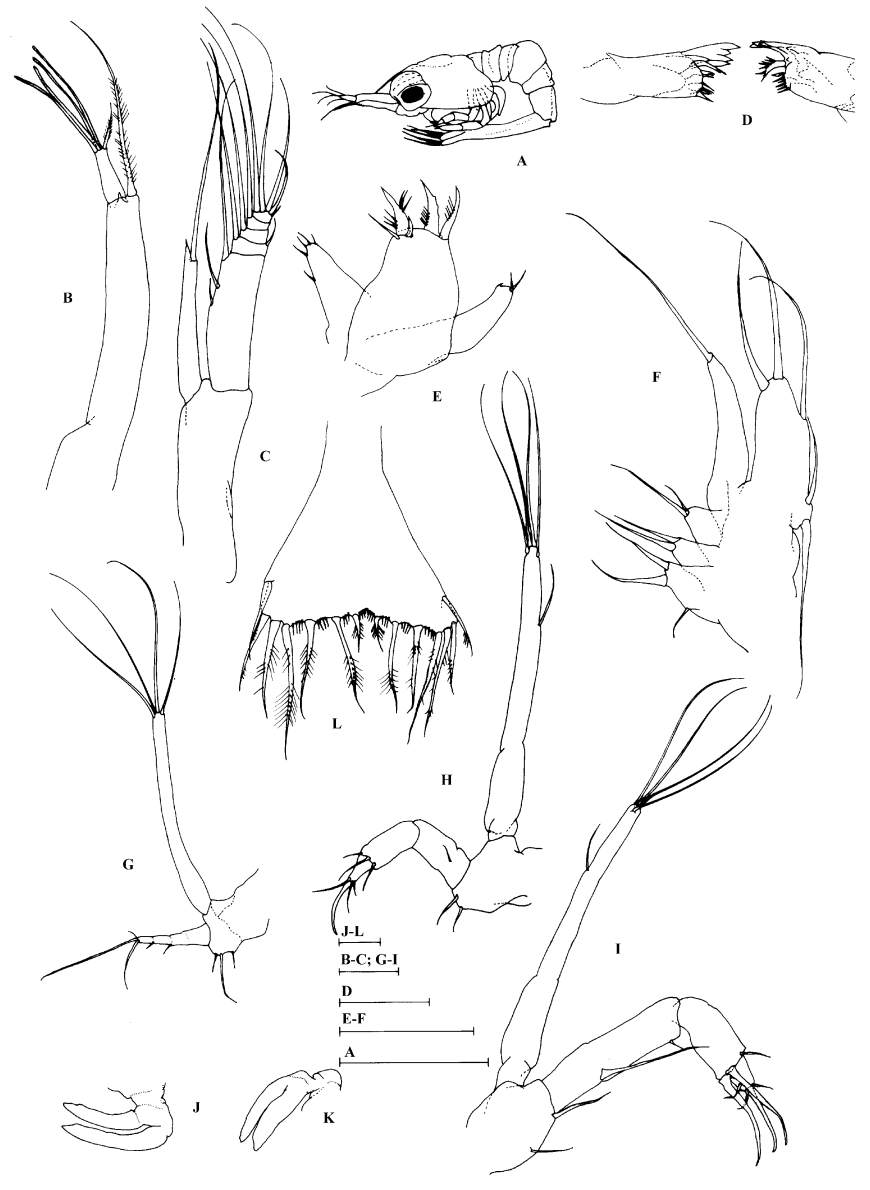

Fig. 1A-L Periclimenes sagittifer, first zoea. A Total animal, lateral view. B Antennule. C Antenna. D Mandibles. E Maxillule. F Maxilla. G First maxilliped. H Second maxilliped. I Third maxilliped. J First pereiopod. K Second pereiopod. L Telson. Scale bar $1.0 \mathrm{~mm}(\mathbf{A}) ; 0.1 \mathrm{~mm}(\mathbf{B}-\mathbf{L})$

being able to settle in the absence of chemical settlement cues. The ten larvae that were placed in small individual plastic containers died a few seconds after entering the container, stung by the tentacles' cnidocytes. Of the ten larvae placed in a mesh basket in an aquarium containing conspecifics and host anemones, a single zoea survived and metamorphosed to the post-larval stage after 7 days.

\section{Description}

Periclimenes sagittifer (Norman, 1861) (Figs. 1, 2, 3, 4, 5, 6)

\section{First zoea}

Dimensions: $\mathrm{TL}=2.14-2.21 \mathrm{~mm} ; \mathrm{CL}=0.58-0.60 \mathrm{~mm}$.

Carapace (Fig. 1A): rostrum slender, pointed downwards, reaching middle of antennular peduncle, eyes compound and sessile; 1 pterigostomial spine.

Antennule (Fig. 1B): peduncle unsegmented, bears 1 long plumose seta terminally, and a small process; short 


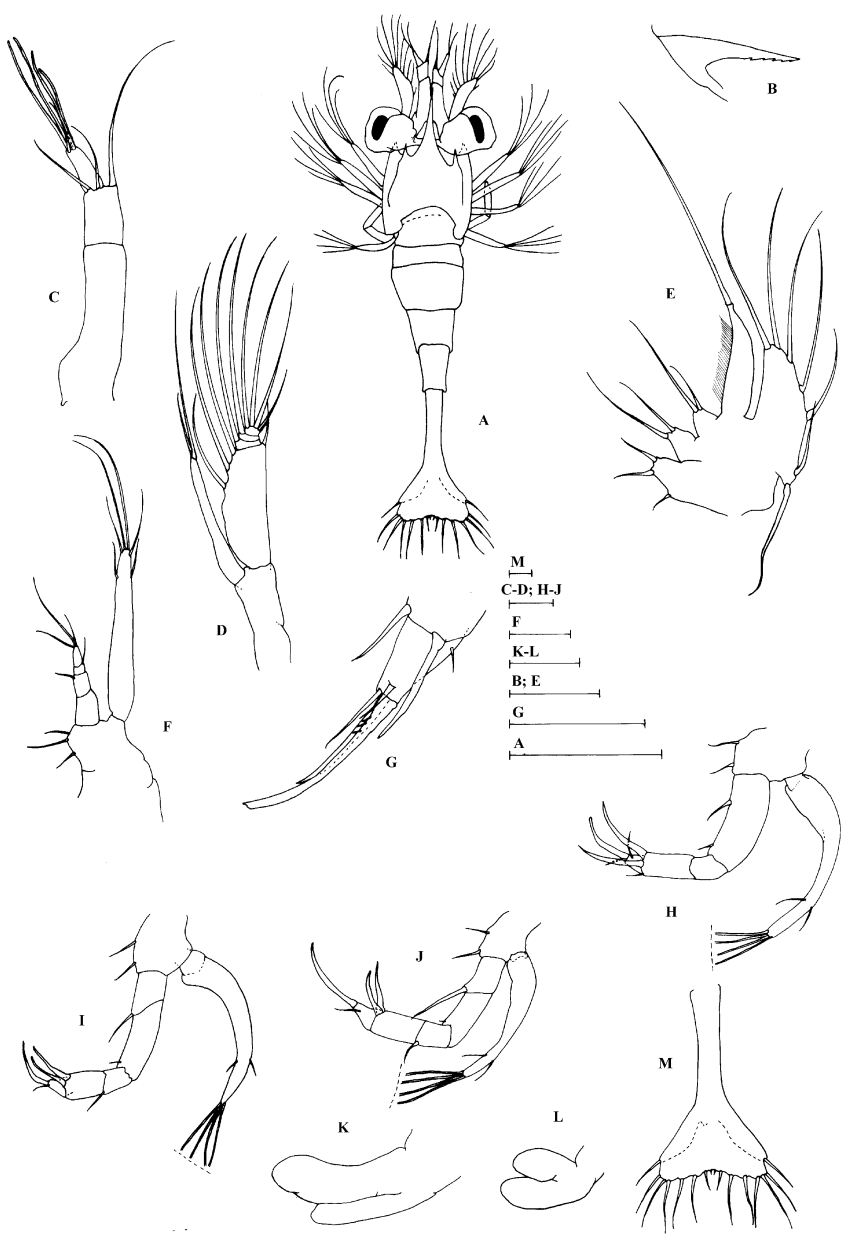

Fig. 2A-M Periclimenes sagittifer, second zoea. A Total animal, dorsal view. B Carapace supraorbital spine. C Antennule. D Antenna. E Maxilla. F First maxilliped. G Second maxilliped, detail of endopod distal segment. H Third maxilliped. I First pereiopod. J Second pereiopod. K Third pereiopod. L Fourth pereiopod. M Telson. Scale bar $1.0 \mathrm{~mm}(\mathbf{A}) ; 0.1 \mathrm{~mm}(\mathbf{B}-\mathbf{M})$

outer flagellum with 1 short plumose seta and 4 aesthetascs.

Antenna (Fig. 1C): protopod unsegmented; endopod apical with 1 long plumose seta and 1 short spine; scaphocerite 5-segmented, 4 short segments distally, with 1 plumose setae on outer side and 10 plumose setae on inner side, plus a simple small seta on apex.

Mandible (Fig. 1D): asymmetrical. Palp absent. Armature of incisor and molar processes as illustrated.

Maxillule (Fig. 1E): coxal endite with 5 simple setae, basal endite with 3 strong setulate setae and 2 strong simple setae; endopod with 1 process on distal end and 2 terminal simple setae; exopod absent.

Maxilla (Fig. 1F): coxal endite not bilobed with 3 strong simple setae, basal endite bilobed with 2 simple setae each; endopod unsegmented bearing 1 long simple setae; exopod with 5 marginal plumose setae.

First maxilliped (Fig. 1G): coxa unarmed; basis with 3 simple setae; endopod weakly 4-segmented with $0,1,1,3$ setae; exopod unsegmented, bearing 4 long plumose setae terminally.

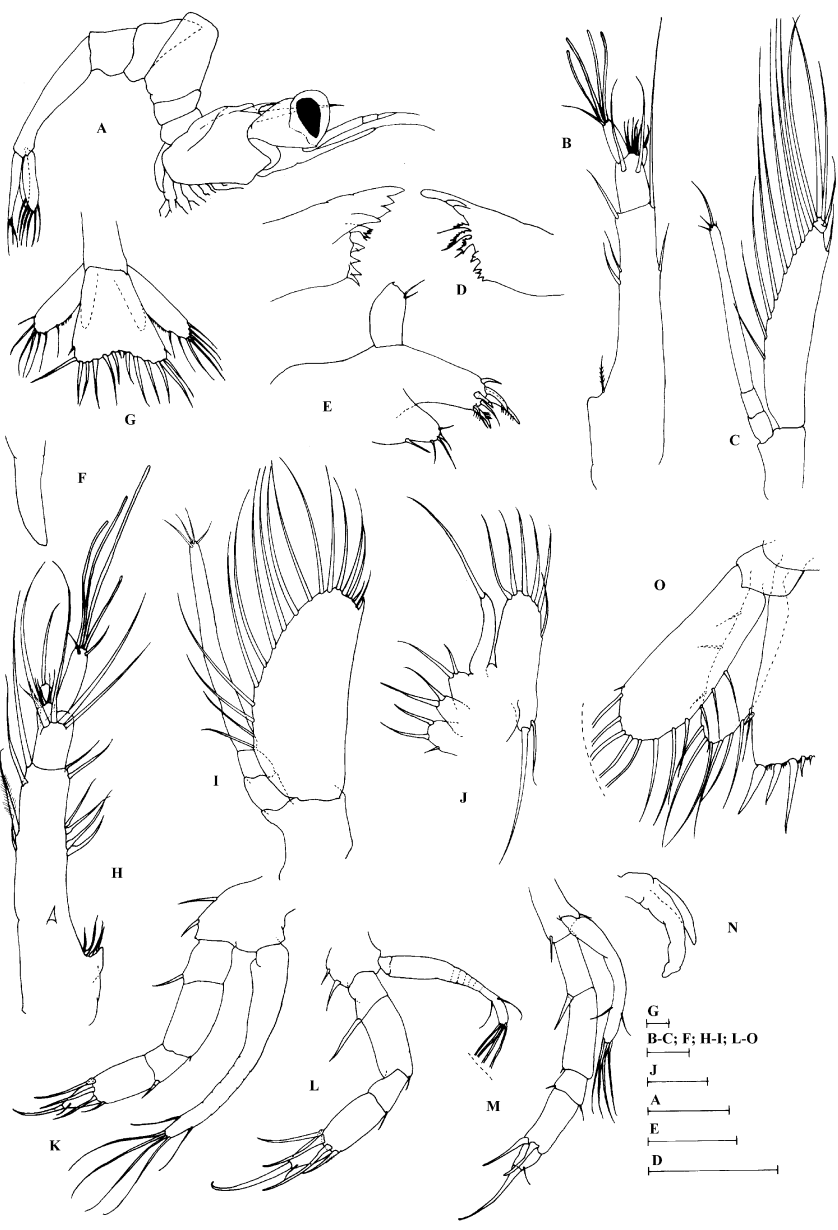

Fig. 3A-O Periclimenes sagittifer. Third zoea: A Total animal, lateral view. B Antennule. C Antenna. D Mandibles. E Maxillule. F Fifth pereiopod. G Telson and uropods. Fourth zoea: H Antennule. I Antenna. J Maxilla. K First pereiopod. L Second pereiopod. M Third pereiopod. N Fourth pereiopod. O Telson and uropods. Scale bar $0.5 \mathrm{~mm}(\mathbf{A}) ; 0.1 \mathrm{~mm}(\mathbf{B}-\mathbf{O})$

Second maxilliped (Fig. 1H): basis with 2 simple setae; endopod 3-segmented with 1, 3, 3+1 setae terminally. Exopod unsegmented, bearing 1+4 plumose setae.

Third maxilliped (Fig. 1I): basis with 2 simple setae; endopod 3-segmented, with $1+1,2+1,3+1$ simple setae; exopod unsegmented, bearing $1+4$ plumose setae.

First pereiopod (Fig. 1J): biramous bud.

Second pereiopod (Fig. 1K): biramous bud.

Third to fifth pereiopods: absent.

Abdomen (Fig. 1A): 5 somites with margins rounded.

Pleopods: absent.

Uropods: absent.

Telson (Fig. 1L): fused with 6th abdominal segment; triangular, broader posteriorly; indented medially with $7+7$ setae (inner 5 plumose, outer 2 plumose on proximal axis only), with the fourth the longest; minute spines between and around setae. 


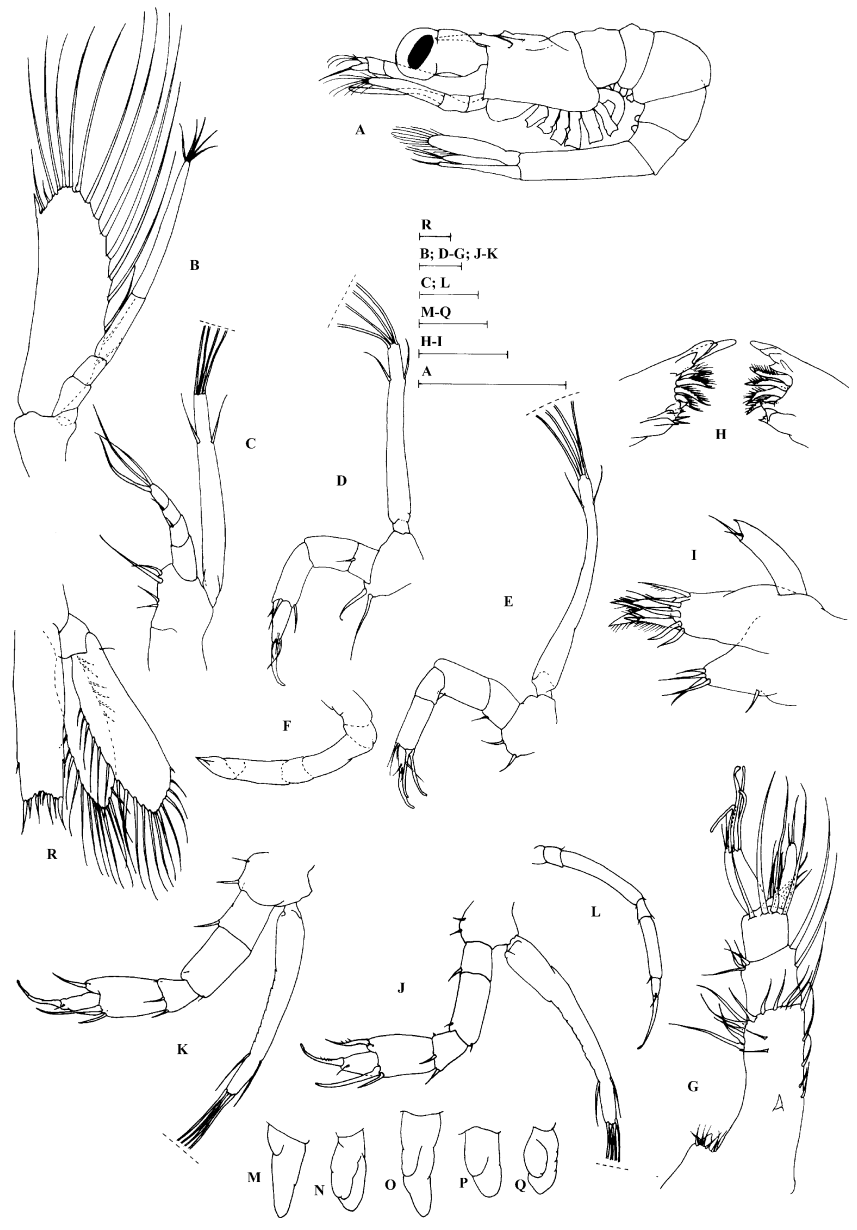

Fig. 4A-R Periclimenes sagittifer. Fifth zoea: A Total animal, lateral view. B Antenna. C First maxilliped. D Second maxilliped. E Third maxilliped. F Fifth pereiopod. Sixth zoea: G Antennule. H Mandibles. I Maxillule. J First pereiopod. K Second pereiopod. L Fifth pereiopod. M First pleopod. N Second pleopod. O Third pleopod. P Fourth pleopod. Q Fifth pleopod. R Telson and uropods. Scale bar $1.0 \mathrm{~mm}(\mathbf{A}) ; 0.1 \mathrm{~mm}(\mathbf{B}-\mathbf{R})$

\section{Second zoea}

Dimensions: $\mathrm{TL}=2.95-3.05 \mathrm{~mm} ; \mathrm{CL}=0.98-1.10 \mathrm{~mm}$.

Carapace (Fig. 2A, B): eyes stalked looking sideways; with a pair of supraorbital ridged spines serrated on ventral margin, the ridge extending back to $2 / 3$ of the carapace; a pair of pterigostomial spines.

Antennule (Fig. 2C): peduncle 2-segmented, posterior segment with 1 long plumose seta and 2 short plumose setae distally; flagellum with 4 aesthetascs and 1 plumose setae.

Antenna (Fig. 2D): protopod unsegmented; endopod with 1 long plumose and 1 short simple setae; scaphocerite 4-segmented, 3 short segments distally, with 1 plumose seta on outer side and 9-10 plumose setae on inner side, plus a simple small seta on apex.

Mandible: unchanged.

Maxillule: basal endite with 3 strong setulate setae and 4 strong simple setae; otherwise unchanged besides size.

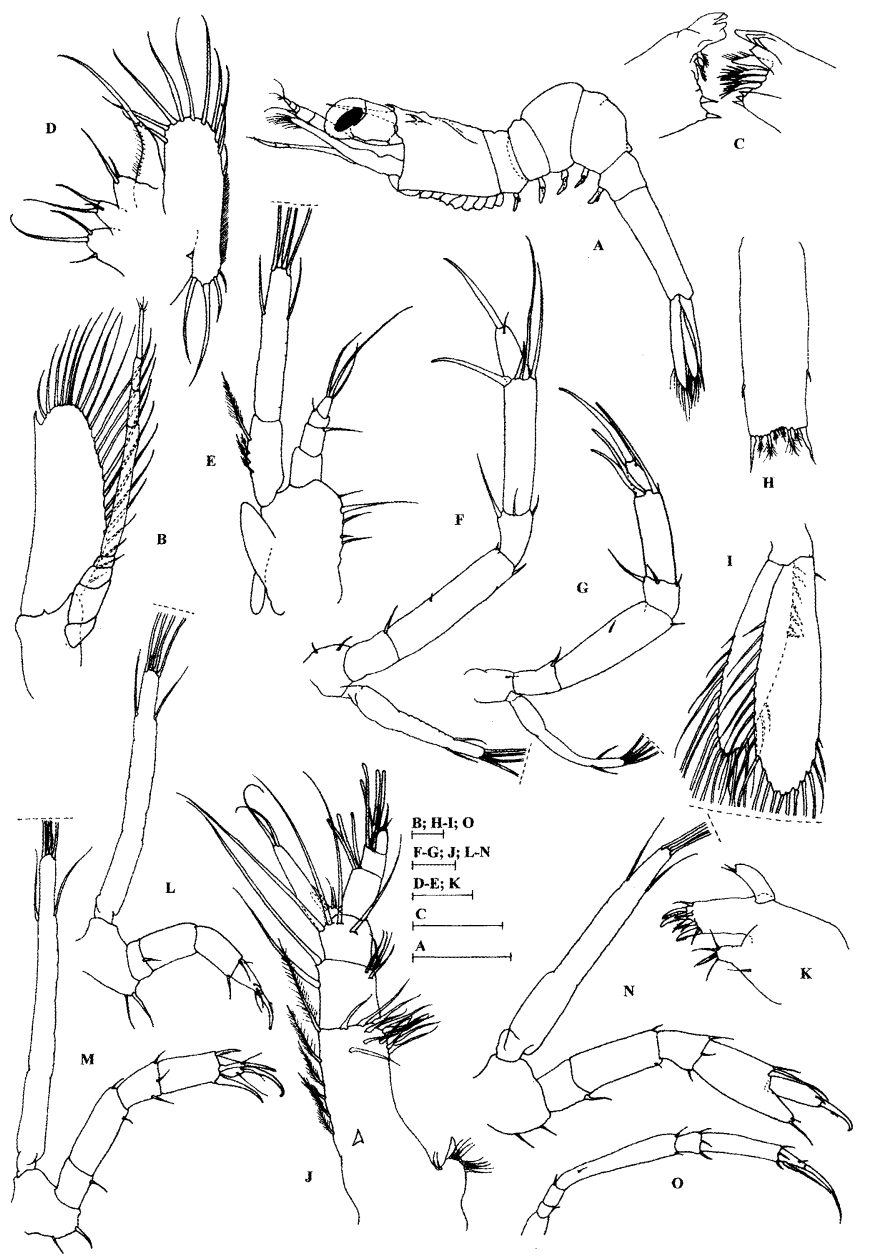

Fig. 5A-O Periclimenes sagittifer. Seventh zoea: A Total animal, lateral view. B Antenna. C Mandibles. D Maxilla. E First maxilliped. F Third pereiopod. G Fourth pereiopod. H Telson. I Uropods. Eighth zoea: J Antennule. K Maxillule. L Second maxilliped. M Third maxilliped. N First pereiopod. O Fifth pereiopod. Scale bar $1.0 \mathrm{~mm}(\mathbf{A}) ; 0.1 \mathrm{~mm}(\mathbf{B}-\mathbf{O})$

Maxilla (Fig. 2E): scaphognathite with 7 marginal plumose setae; otherwise unchanged besides size.

First maxilliped (Fig. 2F): endopod 4-segmented with $0,1,1,3$ setae; exopod bearing 2 shorter plumose setae on lateral margin and 4 long plumose setae terminally; otherwise unchanged besides size.

Second maxilliped (Fig. 2G): endopod 3-segmented, with $1,2,1+3$ simple setae and 1 cuspidate seta on distal segment. Exopod unsegmented with $2+4$ plumose setae; otherwise unchanged besides size.

Third maxilliped (Fig. 2H): endopod 4-segmented, with $1+1,0,2+1,3$ simple setae and 1 cuspidate seta on distal segment; exopod unsegmented, bearing $2+4$ plumose setae; otherwise unchanged besides size.

First pereiopod (Fig. 2I): biramous; basis with 2 simple setae; endopod 5-segmented, with 1, 1, 1, 2, 1+1 simple setae. Exopod unsegmented with $2+4$ plumose setae.

Second pereiopod (Fig. 2J): biramous; basis with 2 simple setae; endopod 5-segmented, with $1,1,1,2,1+1$ 


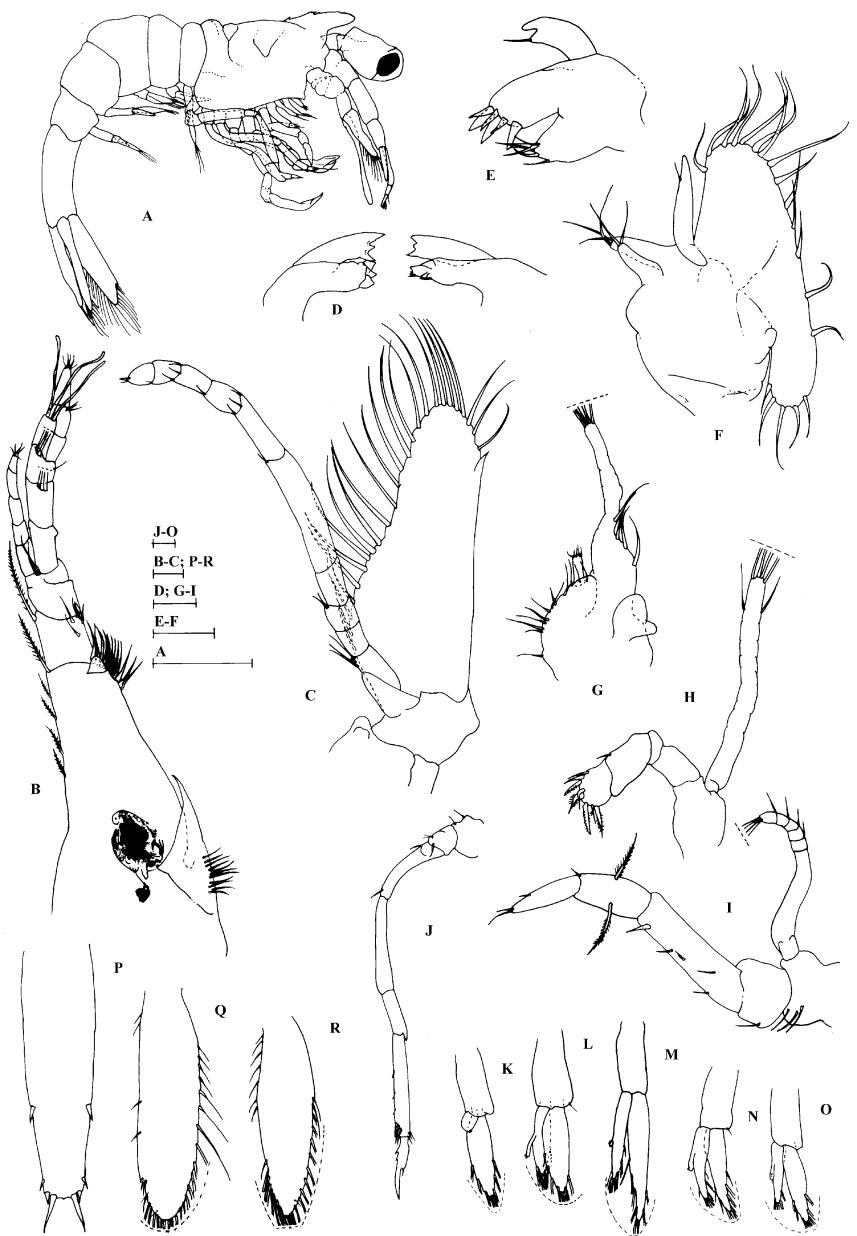

Fig. 6A-R Periclimenes sagittifer. Megalopa: A Total animal, lateral view. B Antennule. C Antenna. D Mandibles. E Maxillule. F Maxilla. G First maxilliped. H Second maxilliped. I Third maxilliped. J Fifth pereiopod. K First pleopod. L Second pleopod. M Third pleopod. N Fourth pleopod. O Fifth pleopod. P Telson. Q Uropods exopod. R Uropods endopod. Scale bar $1.0 \mathrm{~mm}$ (A); $0.1 \mathrm{~mm}(\mathbf{B}-\mathbf{R})$

simple setae. Exopod unsegmented with $2+4$ plumose setae.

Third pereiopod (Fig. 2K): biramous bud.

Fourth pereiopod (Fig. 2L): biramous bud.

Fifth pereiopod: absent.

Abdomen (Fig. 2A): S-shaped, the first bend lying between cephalothorax and abdomen, the second bend in abdominal somite 3 which is bigger than the others.

Pleopods: absent.

Uropods: absent.

Telson (Fig. 2M): $8+8$ plumose setae, the outer ones on proximal axis only.

\section{Third zoea}

Dimensions: $\mathrm{TL}=2.89-3.04 \mathrm{~mm} ; \mathrm{CL}=1.00-1.08 \mathrm{~mm}$. Carapace (Fig. 3A): unchanged besides size.
Antennule (Fig. 3B): peduncle 2-segmented, proximal segment with 1 plumose seta on stylocerite, 3 plumose setae subterminally, 1 simple seta and 1 long plumose seta distally; distal segment bearing 2 plumose setae subterminally and 6 plumose setae on margin. Inner flagellum bearing a simple seta, outer flagellum with 4 aesthetascs and 1 simple seta.

Antenna (Fig. 3C): scaphocerite 2-segmented, with 12 plumose setae on inner margin, 1 simple small seta on apex, and 1 plumose seta on outer margin. Endopod 3 -segmented (2 short basal segments and 1 long distal segment), with 4 simple setae terminally.

Mandible (Fig. 3D): right mandible with 1 more tooth on incisive part; otherwise unchanged besides size.

Maxillule (Fig. 3E): unchanged besides size.

Maxilla: unchanged besides size.

First maxilliped: unchanged besides size.

Second maxilliped: unchanged besides size.

Third maxilliped: endopod 4-segmented, with $1+1,0$, $2+3,3$ simple setae and 1 cuspidate seta on distal segment. Otherwise unchanged.

First pereiopod: endopod 5-segmented, with 1, 1, 1, $2+1,1+1$ simple setae. Otherwise unchanged.

Second pereiopod: endopod 5-segmented, with 1, 1, 1, 2+1,1+1 simple setae.

Third pereiopod: unchanged.

Fourth pereiopod: unchanged.

Fifth pereiopod (Fig. 3F): uniramous bud.

Abdomen (Fig. 3A): abdominal somite 6 separated from telson; otherwise unchanged.

Pleopods: absent.

Uropod (Fig. 3G): biramous; exopods well-developed not reaching the end of telson, with 6 plumose setae; endopod small without setae.

Telson (Fig. 3G): first pair of setae shorter, with a subterminal position.

\section{Fourth zoea}

Dimensions: $\mathrm{TL}=3.62-3.81 \mathrm{~mm} ; \mathrm{CL}=1.23-1.31 \mathrm{~mm}$.

Carapace: rostrum with 1 dorsal spine; 1 small antennal spine before the pterigostomial spine. Otherwise unchanged.

Antennule (Fig. 3H): peduncle 2-segmented, proximal segment with 4 plumose setae on stylocerite, $6+4$ plumose setae, 1 strong spine on the first third of segment; distal segment with 4 long plumose setae and 6 plumose setae distributed on distal margin of a small process. Inner flagellum bearing 1 simple seta, outer flagellum with 4 aesthetascs and 2 small plumose setae.

Antenna (Fig. 3I): scaphocerite unsegmented, about 2.3 times longer than wide; outer margin terminates in a spine, inner margin with 16-17 plumose setae; endopod reaching the end of scaphocerite.

Mandible: unchanged.

Maxillule: unchanged besides size.

Maxilla (Fig. 3J): scaphognathite with 8 plumose setae; otherwise unchanged. 
First maxilliped: unchanged.

Second maxilliped: endopod 4-segmented with 1, 0, 2, 3 simple setae and 1 cuspidate seta on distal segment; otherwise unchanged.

Third maxilliped: unchanged.

First pereiopod (Fig. 3K): endopod longer than exopod, 5-segmented, with 1, 1, 1, 4 (1 setulate) plumose setae on first four segments, 1 simple seta and 1 strong setulate seta on distal segment; otherwise unchanged.

Second pereiopod (Fig. 3L): endopod longer than exopod, 5-segmented, with 1, 1, 1, 4 (1 setulate) plumose setae on first four segments, 1 simple seta and 1 strong setulate seta on distal segment; otherwise unchanged.

Third pereiopod (Fig. 3M): biramous; basis with 2 simple setae; endopod 5-segmented, with 1, 1, 2, 2,1+1 simple setae. Exopod unsegmented with $2+4$ plumose setae.

Fourth pereiopod (Fig. 3N): unchanged.

Fifth pereiopod: unchanged.

Abdomen: unchanged besides size.

Pleopods: absent.

Uropods (Fig. 30): exopods reaching the posterior margin of telson, with 11-12 sparsely plumose setae distributed on the inner and bottom margins, outer margin with 1 spine on apex; endopods with 6-7 plumose setae on bottom margin and 3 sparsely simple setae on outer margin.

Telson (Fig. 3O): almost rectangular; 1 pair of lateral spines, bears 5 pairs of plumose setae on the posterior end.

\section{Fifth zoea}

Dimension: $\mathrm{TL}=4.00-4.15 \mathrm{~mm} ; \mathrm{CL}=1.31-1.39 \mathrm{~mm}$.

Carapace (Fig. 4A): unchanged.

Antennule: peduncle 2-segmented, proximal segment with 4 plumose setae on stylocerite, 6 plumose setae on median border, 5 plumose setae along inner margin, 2 plumose setae on distal margin and 1 strong spine on the first third of segment; distal segment with 4 long plumose setae and 6 plumose setae distributed on distal margin of a small process; otherwise unchanged.

Antenna (Fig. 4B): endopod 4-segmented, longer than scaphocerite, with 5 simple setae terminally.

Mandible: left mandible with 1 more tooth on incisive part; otherwise unchanged besides size.

Maxillule: basal endite with 3 strong setulate setae and 4-5 strong setae; otherwise unchanged beside size.

Maxilla: scaphognathite with 8-9 plumose setae; otherwise unchanged.

First maxilliped (Fig. 4C): basis with 3-4 simple setae. Otherwise unchanged.

Second maxilliped (Fig. 4D): unchanged.

Third maxilliped (Fig. 4E): endopod 5-segmented with $1,1,0,2+3,3$ simple setae and 1 cuspidate seta on distal segment; otherwise unchanged.

First pereiopod: unchanged besides size.

Second pereiopod: unchanged.
Third pereiopod: unchanged.

Fourth pereiopod: unchanged.

Fifth pereiopod (Fig. 4F): unchanged.

Abdomen (Fig. 4A): unchanged.

Pleopods (Fig. 4A): uniramous bud.

Uropods: unchanged besides size.

Telson: margins laterally parallel, with median cleft.

\section{Sixth zoea}

Dimensions: $\mathrm{TL}=4.23-4.42 \mathrm{~mm} ; \mathrm{CL}=1.42-1.50 \mathrm{~mm}$.

Carapace: rostral dorsal spine serrated on ventral margin; otherwise unchanged.

Antennule (Fig. 4G): peduncle 3-segmented, proximal segment with 7 plumose setae on stylocerite, $12-13$ plumose setae on distal margin, 5 plumose setae along inner margin, and 1strong spine on the first half of segment and a dense circular mass suggesting a statocyst; 2 nd segment with 2 long plumose setae on inner margin and 4 plumose setae on distal margin; distal segment with 4 long plumose setae and 6 plumose setae distributed on distal margin of a small process; inner flagellum with 2 simple setae; otherwise unchanged.

Antenna: scaphocerite with 19-20 plumose setae; endopod 5-segmented; otherwise unchanged.

Mandibles (Fig. 4H): right mandible with 1 more tooth on incisive part; otherwise unchanged.

Maxillule (Fig. 4I): coxal endite with 5-6 simple setae; otherwise unchanged.

Maxilla: scaphognathite with 11 plumose setae; otherwise unchanged.

First maxilliped: basis with $2+2+1$ setae; otherwise unchanged.

Second maxilliped: unchanged.

Third maxilliped: endopod 5-segmented, with 1, 2, 3, $3+2,3$ apical simple setae and 1 setulate seta on distal segment; otherwise unchanged.

First pereiopod (Fig. 4J): endopod 5-segmented, with $1,2,3,3+1,1+1$ setae, with internal distal margin of propodus produced forward to about one third of dactylus; otherwise unchanged.

Second pereiopod (Fig. 4K): endopod 5-segmented, with $1,2,3,3+1,1+1$ setae, with internal distal margin of propodus produced forward to about one third of dactylus; otherwise unchanged.

Third pereiopod: endopod 5-segmented, with 1, 2, 3, 4,1 simple setae and 1 setulate seta on distal segment; otherwise unchanged.

Fourth pereiopod: biramous, basis with 1 seta; endopod 5-segmented, with 1, 1, 2, 2, 1+1 setae; exopod unsegmented with $2+4$ plumose setae.

Fifth pereiopod (Fig. 4L): uniramous; basis unarmed; 5-segmented, with 1, 2, 2, 1, 1+1 setae.

Abdomen: unchanged.

Pleopods (Fig. 4M-Q): biramous buds.

Uropods (Fig. 4R): exopods beyond the posterior margin of telson, with 1 simple seta on outer proximal margin and with 1 spine on apex, 16-17 sparsely plumose 
setae distributed on the inner and bottom margins; endopods with 11-12 plumose setae on bottom margin and 5-6 sparsely simple setae on outer margin.

Telson (Fig. 4R): tapers towards posterior end, bears $6+6$ setae terminally, with 1 pair of simple setae laterally.

\section{Seventh zoea}

Dimensions: $\mathrm{TL}=5.11-5.38 \mathrm{~mm} ; \mathrm{CL}=1.72-1.83 \mathrm{~mm}$.

Carapace (Fig. 5A): unchanged.

Antennule: peduncle 3-segmented, proximal segment with 10-11 plumose setae on stylocerite, 12-14 plumose setae on distal margin, 5 plumose setae along inner margin, and 1 strong spine on the first half of segment; 2nd segment with 2 long plumose setae on inner margin and 4 plumose setae on distal margin; distal segment with 4 long plumose setae and 6 plumose setae distributed on distal margin of a small process; outer flagellum 2-segmented, proximal segment with 3 aesthetascs, distal segment with 4 aesthetascs subterminally and 2 simple setae terminally; otherwise unchanged.

Antenna (Fig. 5B): basis with a small spine; scaphocerite with 22-23 plumose setae; endopod 8-segmented; otherwise unchanged.

Mandibles (Fig. 5C): unchanged.

Maxillule: unchanged.

Maxilla (Fig. 5D): basis with $3+2$ simple setae; scaphognathite with 14-15 plumose setae; otherwise unchanged.

First maxilliped (Fig. 5E): coxal endite with buds of epipodite and branchia; exopod 2-segmented, proximal segment with 1 or 4 plumose setae, distal segment with $2+4$ plumose setae; otherwise unchanged.

Second maxilliped: endopod distal segment with $1+3$ simple setae and 1 setulate seta; otherwise unchanged.

Third maxilliped: unchanged.

First pereiopod: unchanged besides size

Second pereiopod: unchanged besides size.

Third pereiopod (Fig. 5F): endopod 5-segmented, with $1,1+2,3,4,1$ simple setae and 1 setulate seta on distal segment; otherwise unchanged.

Fourth pereiopod (Fig. 5G): endopod 5-segmented, with $1,1+1,3,4,1+1$ setae; otherwise unchanged.

Fifth pereiopod: coxa unarmed; basis with 1 seta; merus with $1+2$ simple setae, carpus with 3 simple setae, propodus with 3 simple setae, dactyl with $1+1$ setae.

Abdomen (Fig. 5A): unchanged.

First to fifth pleopods (Fig. 5A): more developed, with protopod.

Uropods (Fig. 5I): exopods with 1 simple seta on outer proximal margin and with 1 spine on apex, 18-20 sparsely plumose setae distributed on the inner and bottom margins; endopods with 15-16 plumose setae on bottom margin and 6-8 sparsely simple setae on outer margin.

Telson (Fig. 5H): posterior end bears $5+5$ setae terminally, in which 3 rd-5th setae are plumose, otherwise unchanged.

\section{Eight zoea}

Dimensions: $\mathrm{TL}=4.88-5.35 \mathrm{~mm}$; $\mathrm{CL}=1.68-1.83 \mathrm{~mm}$.

Carapace: unchanged.

Antennule (Fig. 5J): peduncle 3-segmented, proximal segment with 11-12 plumose setae on stylocerite, 13-14 plumose setae on distal margin, 5-6 plumose setae along inner margin, and 1 strong spine on the first half of segment; 2nd segment with 2 long plumose setae on inner margin and 5-6 plumose setae on distal margin; distal segment with 4 long-plumose setae and 5-6 plumose setae distributed on distal margin of a small process; outer flagellum 3-segmented, proximal segment with 3 aesthetascs, 2nd segment with 4 aesthetascs and distal segment with 2 simple setae; otherwise unchanged.

Antenna: scaphocerite with 22-24 plumose setae; flagellum composed of 8 segments, with 1 seta on 6th and on 7 th and 5 setae on the last segment, the remaining segments were without setae on distal margin; otherwise unchanged.

Mandibles: left mandible with 1 more tooth on incisive part; otherwise unchanged.

Maxillule (Fig. 5K): unchanged.

Maxilla: unchanged.

First maxilliped: basis with 6-7 setae; otherwise unchanged besides size.

Second maxilliped (Fig. 5L): unchanged besides size.

Third maxilliped (Fig. 5M): endopod 4th segment with 2 simple and 1 setulate setae; otherwise unchanged.

First pereiopod (Fig. 5N): chelae more developed; otherwise unchanged.

Second pereiopod: chelae more developed; otherwise unchanged.

Third pereiopod: unchanged besides size.

Fourth pereiopod: unchanged besides size.

Fifth pereiopod (Fig. 5O): dactyl with 1 more simple seta subterminally.

Abdomen: unchanged.

First pleopod: unchanged besides size.

Second to fourth pleopods: with small bud of appendix interna.

Fifth pleopod: unchanged besides size.

Uropods: exopods with 1 simple seta on outer proximal margin and with 1 spine on apex, 20-22 sparsely plumose setae distributed on the inner and bottom margins; endopods with $16-18$ plumose setae on bottom margin and 6-8 sparsely simple setae on outer margin.

Telson: narrower distally than proximally; otherwise unchanged.

\section{Megalopa}

Dimensions: $\mathrm{TL}=4.09 \mathrm{~mm} ; \mathrm{CL}=1.18 \mathrm{~mm}$.

Carapace (Fig. 6A): carapace smooth with branchiocardiac and gastro-orbital carinas incomplete and without supraorbital spines; rostrum damaged with 3 small dorsal spines. 
Antennule (Fig. 6B): peduncle 3-segmented, proximal segment with statocyste, 11 simple setae on stylocerite, 12 plumose setae and a small process on outer distally margin and 5 plumose setae along inner margin; 2nd segment with 1 long plumose seta on inner margin and 6 sparsely plumose setae distributed on distal margin; distal segment with 2 plumose setae on distal margin; outer flagellum biramous with three proximal segments fused, short free ramus with 1 segment bearing 3 aesthetascs, longer free ramus 3-segmented with 3 simple setae on 2nd segment and 5 on distal segment; inner flagellum 5-segmented with 5 simple setae terminally.

Antenna (Fig. 6C): basis with 1 spine on outer margin; scaphocerite with 25 plumose setae sparsely distributed along inner margin and 1 spine on distal outer margin; flagellum composed of 10 segments, each with 0-3 simple setae on distal margin, arranged as figured.

Mandibles (Fig. 6D): incisor process slender with 3 distal teeth; molar process with 3 blunt distal teeth.

Maxillule (Fig. 6E): coxa with 6 simple setae; basis with 6 strong spines; endopod bilobed with single simple seta on lower lobe.

Maxilla (Fig. 6F): basis bilobed with $2+3$ simple setae; endopod with 1 small subterminally simple seta; scaphognathite with 19 plumose setae.

First maxilliped (Fig. 6G): coxa and basis fused with 12 simple setae; unsegmented endopod with 5 terminal simple small setae; exopod unsegmented with 4 plumose setae on proximal lobe and 4 plumose setae on distal margin; epipodite present.

Second maxilliped (Fig. 6H): basis unarmed; endopod 4-segmented with 1 simple seta on 3rd segment and 8 strong short plumose setae on distal segment margin; exopod unsegmented with $2+4$ plumose setae.

Third maxilliped (Fig. 6I): basis with 3 simple submarginal setae; endopod 4-segmented with 1 simple seta on proximal segment, 4 simple setae and 1 spine along distolateral margin on 2nd segment, 2 strong plumose setae medially and 2 simple distal setae on 3rd segment and 4 simple setae ( 2 along lateral margin and 2 terminally) on distal segment; exopod 6-segmented with 1,1 , 1, 1, 4 simple setae on last 5 segments.

First pereiopod: coxa with 3 simple setae on distal margin, basis with 1 simple seta on lateral margin; propodus with a stout distal spine and a second one on lateral margin, dactylus with one submarginal tooth, forming a chela, all other segments well-differentiated and unarmed; exopod reduced and unsegmented.

Second pereiopod: coxa with 2 simple setae on distal inner margin; basis unarmed; ischium with 1 simple seta on distal outer margin; propodus forming the chela with $2+2$ stout teeth and 6 simple setae, dactylus with 1 stout tooth and 5 simple setae; exopod reduced and unsegmented.

Third pereiopod: coxa with 3 simple setae on distal margin; basis with 2 simple setae on distal inner margin; ischium with 1 simple seta; carpus with 1 spinous process; propodus not chelate with 4 simple setae along outer margin, 1 spine on distal inner margin and 3 strong simple setae on distal outer margin; dactylus with bifurcated distal margin; exopod reduced and unsegmented.

Fourth pereiopod: coxa with 3 simple setae on distal margin; basis with 2 simple setae on distal inner margin; ischium with 1 simple seta; carpus with 1 spinous process; propodus not chelate with 4 simple setae along outer margin, 3 small spines on distal inner margin and 3 strong simple setae on distal outer margin; dactylus with bifurcated distal margin; exopod reduced and unsegmented.

Fifth pereiopod (Fig. 6J): coxa with 2 simple setae on distal margin; basis with 2 simple setae on distal inner margin; ischium with 1 simple seta; carpus with 1 spinous process; propodus not chelate with 3 simple setae along outer margin, 3 small spines on distal inner margin and 3 strong simple setae on distal outer margin; dactylus with bifurcated distal margin and 2 teeth on outer lateral margin.

Abdomen (Fig. 6A): 6 somites and a rectangular telson; each somite with well-developed pleopods.

Pleopods (Fig. 6K-O): well-developed, biramous, endopod without setae on 1st pleopod and 5-8 setae sparsely distributed on 2nd-5th pleopods; exopod with 8 setae on 1st pleopod and 8-9 setae sparsely distributed on 2nd -5 th pleopods; epipodite always present with 2 cincinulli.

Uropod (Fig. 6Q-R): endopod with 23 plumose and 7 simple setae marginally and 1 setae dorsally on distal margin; exopod with 2 spines, 24 plumose setae marginally and 4 simple setae on outer margin and 2 simple setae on dorsal outer margin.

Telson (Fig. 6P): telson with 2 pairs of spines on distal margin and 2 pairs on dorsolateral margin.

\section{Discussion}

Periclimenes sagittifer larvae have the characteristics typically attributed to Periclimenes species: an S-shaped body, with the first bend lying between cephalotorax and abdomen and the second bend in the third abdominal somite; eyes looking sideways and long supraorbital spines, serrated on the ventral margin.

Concerning Periclimenes larvae described from Mediterranean waters, all authors agree with BourdillonCasanova's (1960) description of a larval series attributed with some reservations to $P$. scriptus. Periclimenes sagittifer larvae described in the present paper agree with Bourdillon-Casanova's description in all main morphological characteristics and in the number of zoeal stages (eight). The minor differences found are attributed to a less detailed description made by the previous author. Periclimenes larvae from Marseille waters present an antennal spine from zoea III to the last zoeal stage, while in $P$. sagittifer the antennal spine appears at the fourth zoeal stage. However, it is impossible to describe characteristics that distinguish between the larvae described by Bourdillon-Casanova (1960), the Mediterranean species of the amethysteus complex, and the $P$. sagittifer of the present study. 
Concerning the larvae found in plankton samples in northeastern Atlantic waters, Paula (1982) describes Periclimenes sp. last-stage larvae found in plankton samples off of the southwestern Portuguese coast. His Periclimenes description differed from that of BourdillonCasanova (1960) in that the antennal spine was absent and two spines were present on the dorsolateral margin of the rostrum instead of one. As $P$. sagittifer larvae never possess two spines on the dorsolateral margin of the rostrum, the specimen collected by Paula (1982) must belong to some other Periclimenes species. Dos Santos (1999) also presents some figures attributed to a Periclimenes sp. larvae found in Portuguese waters but the maxilla described had $1+2$ setae in the basipodite instead of the $2+2$ setae displayed by $P$. sagittifer. Again this present study would suggest that these larvae also belong to another Periclimenes species, and probably more than just two species of this genus occur in northeastern Atlantic waters (d'Udekem d'Acoz 1996).

Although more than 160 species are assigned to Periclimenes, all mostly occurring in tropical and subtropical seas of the world (Chace and Bruce 1993), the present work is the first complete description of the larval development of a Periclimenes species cultured under laboratory conditions. However, the first zoeal stages of $P$. agag Kemp, 1922; P. americanus (Kingsley, 1878); $P$. calmani Tattersall, 1921; $P$. diversipes Kemp, 1922; $P$. grandis Stimpson, 1860; and $P$. pandionis Holthuis, 1951 have also been described from eggs hatched in the laboratory. Table 1 summarises the morphological features of these larvae and the ones recorded for $P$. sagittifer. Although the first larvae of all these seven species are similar in general form, they present several differences among them. Periclimenes sagittifer larvae are the largest and the only ones that possess one outer seta on the antenna exopod, while all others display two setae. Additionally, $P$. sattifer has a more developed first maxilliped, possessing four segments on the endopod, while in $P$. agag, $P$. diversipes and $P$. grandis, the endopod of the first maxilliped is unsegmented, $P$. americanus presents two segments, and $P$. pandionis has three segments. Periclimenes calmani presents a pair of lateral spines on the fifth abdominal segment, a particular feature that is not shared with the other species' larvae. Apart from those particularities, the first zoea of $P$. sagittifer, $P$. calmani and $P$. americanus share the same number of antennal distal segments (four), while all other species have three distal segments. The number of maxillule endopod distal spines (two) is also common to these three species, while the remaining larvae have only a single spine on the endopod of the maxillule. Other differences such as the rostrum size, telson type and the number of segments of the maxillipeds endopods are emphasized among all the species. Therefore the present study can establish some features shared by all Periclimenes first zoeal stages: They all have a smooth carapace with a distinct rostrum, which may reach the middle of the antennular peduncle, a smooth abdomen and a telson posterior margin nearly straight or with a small median notch.

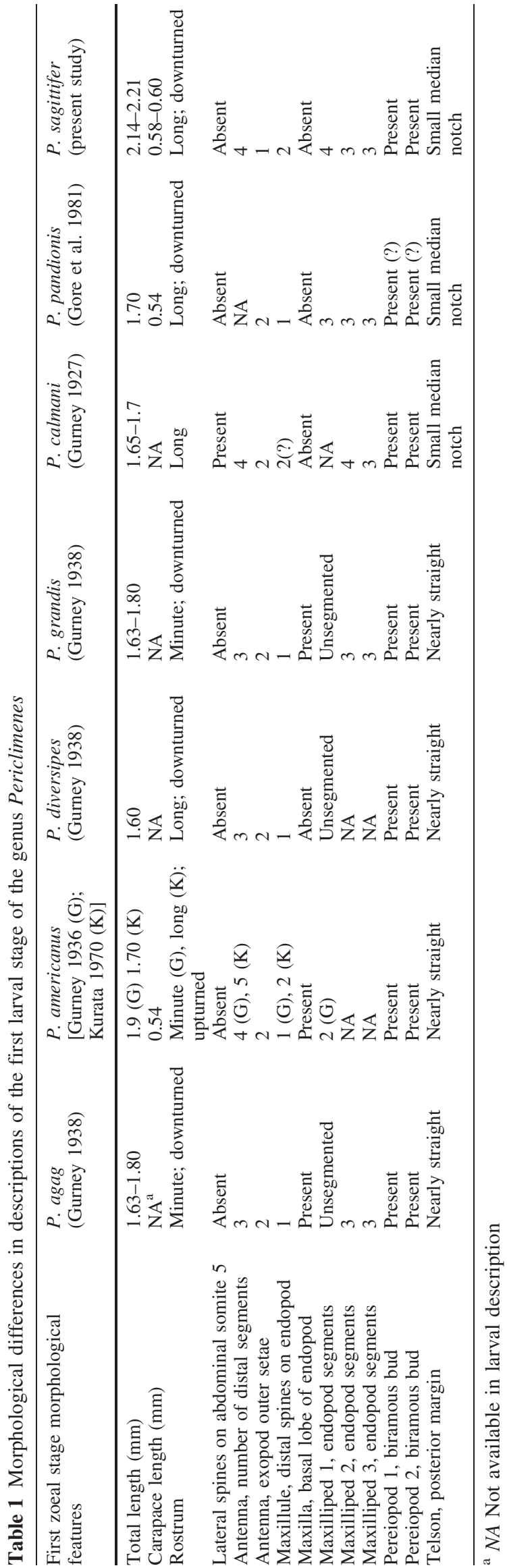


The first two pereiopods are present as biramous buds while the others are absent. The maxillipeds are all developed with four plumose setae on the posterior end of exopod and the antennal exopod displays three to four segments on the distal end.

The settlement of decapod larvae may be triggered by several cues (Forward et al. 1994; Strasser and Felder 1998), namely by the exudates of host species of decapods displaying symbiotic behaviour (Castro 1978; Pohle and Telford 1981; Goy 1990). In the present work only a single larva of $P$. sagittifer exposed to the exudates of its host anemone and conspecifics was able to metamorphose. Though further studies are required, this result seems to indicate that larvae of this species respond to the presence of settlement cues. Goy (1990) recorded a similar observation with the larvae of Periclimenes pedersoni Chace, 1958 and P. yucatanicus (Ives, 1891) when exposed to the exudates of the anemones Bartholomea Duchassing de Fombressin and Michelotti, 1864 and Condylactis Duchassing de Fombressin and Michelotti, 1864, respectively. The reduced survival rate of the larvae exposed to the settlement cues may be explained by the occurrence of mark-time moulting in the last zoeal stage, also known as terminally additive moulting (Gore 1985). This type of moulting was easily diagnosed by the increase in size of last-stage larvae and by the absence of any significant morphological changes. Though larval stage duration could not be accurately monitored in the present work due to the use of a large-scale culture system, the first seven zoeal stages were estimated to have an average duration of 2 days per stage. If the same moulting pattern was maintained during the last larval stage, as many as 15 instars may have occurred. Gore (1985) noted that a large number of terminally additive moults generally result in the death of the larva. In this way, since the larvae were only exposed to settlement cues 20 days after moulting to the eighth zoeal stage, their competence may have been negatively affected, with only one larva being able to settle. High mortality rates have also been recorded for other late-stage decapod larvae delaying metamorphosis (Harms 1992; Calado et al. 2001; Gebauer et al. 2002). These mortality rates may be explained by the use of energy reserves during additional development by late-stage larvae (Anger 2001).

As recorded in the present work, the direct contact between larvae and the host anemones of shrimp living in symbiotic association resulted in the death of the larvae (Sarver 1979; Knowlton and Keller 1986; Goy 1990). These results suggest that the acclimation to the anemone nematocysts must occur in juvenile and not larval stages (Nizinski 1989).

In order to establish commercial culture of Periclimenes for the aquarium trade, future work should address in more detail the role of conspecifics and host anemone exudates in the settlement of late-stage larvae and evaluate the existence of synergetic effects in the presence of both cues. Additionally, the larval development of the remaining species of the amethysteus group, with special emphasis on $P$. aegylios should also be in- vestigated. The knowledge of the larval features of these species will certainly be a valuable tool in the clarification of the systematic position of these closely related species.

Acknowledgements The authors would like to thank the Fundaçăo para a Ciência e a Tecnologia (scholarship SFRH/BD/983/2000 and research project POCTI/BSE/43340/2001) and FEDER (SIGAP Project 22-05-01-FDR-00013) from the Portuguese government, and Cooperation Project No. $456 \mathrm{~N} 1$ from the French and Portuguese governments for their financial support. We would also like to express our sincere gratitude to our colleagues N. Boury-Esnault, A.J. Almeida, J.-G. Harmelin, P. Chevaldonné and M. Alfredo for their diving assistance. The experiments described here were performed according to the current Portuguese and EU laws for scientific research.

\section{References}

Anger K (2001) The biology of decapod crustaceans larvae. AA Balkema, Rotterdam

Bourdillon-Casanova L (1960) Le meroplancton du Golfe de Marseille: les larves des crustacés decapodes. Rec Trav St Mar Endoume 30:1-286

Calado R, Martins C, Santos O, Narciso L (2001) Larval development of the Mediterranean cleaner shrimp Lysmata seticaudata (Risso, 1816) (Caridea: Hippolytidae) fed on different diets - costs and benefits of mark-time molting. In: Hendry CI, Van Stappen G, Wille P, Sorgeloos P (eds) Larvi '01, Fish and Crustacean Larviculture Symposium. European Aquaculture Society, Belgium, pp 96-99

Calado R, Narciso L, Araújo R, Lin J (2003a) Overview of marine ornamental shrimp aquaculture. In: Cato JC and Brown CL (eds), Marine ornamental species - collection, culture \& conservation. Iowa State Press, Iowa City, pp 221-230.

Calado R, Lin J, Rhyne AL, Araújo R, Narciso L (2003b) Marine ornamental decapods-popular, pricey, and poorly studied. J Crust Biol 23:963-973.

Calado R, Narciso L, Morais S, Rhyne AL, Lin J (2003c). A rearing system for the culture of ornamental decapod crustacean larvae. Aquaculture 218:329-339

Castro P (1978) Settlement and habitat selection in the larvae of Echinoecus pentagonus (A. Milne Edwards), a brachyuran crab symbiotic with sea urchins. J Exp Mar Biol Ecol 34:259-270

Chace Jr F, Bruce AJ (1993) The caridean shrimps (Crustacea: Decapoda) of the Albatross Expedition, 1907-1910. Part 6: superfamily Palaemonoidea. Smiths Contrib Zool 543:1-152

Clark PF, Calazans DK, Pohle GW (1998) Accuracy and standardization of brachyuran larval descriptions. Inv Rep Dev 33:127-144

Corbin JS (2001) Marine ornamentals 1999. Conference highlights and priority recommendations. Aquar Sci Conserv 3:3-11

Dos Santos A (1999) Larvas de crustáceos decápodes ao largo da Costa Portuguesa. Ph.D. Dissertation, Faculdade de Cięncias da Universidade de Lisboa, Portugal

Forward Jr R, Frankel D, Rittschof D (1994) Molting of megalopae from the blue crab Callinectes sapidus: effect of offshore and estuarine cues. Mar Ecol Prog Ser 113:55-59

García-Raso JE, Manjón-Cabeza M, Martínez J (1998) Considerations on some species of Hippolyte (Decapoda, Caridea) from southern Europe waters, $H$. niezabitowskii, $H$. holthuisi, and $H$. varians. Crustaceana 71:453-467

Gebauer P, Paschke K, Anger K (2002) Metamorphosis in the semiterrestrial crab, Sesarma curacaonense: intra- and interspecific settlement cues from adult odors. J Exp Mar Biol Ecol 268:1-12

González-Gordillo JI, dos Santos A, Rodríguez A (2001) Checklist and annotated bibliography of decapod crustacean larvae from the southwestern European coast (Gibraltar Strait area). Sci Mar 65:275-305 
Gore R (1985) Molting and growth in decapod larvae. In: Wenner AM (ed) Crustacean issues, vol 2-larval growth. AA Balkema, Rotterdam, pp 1-65

Gore R, Van Dover C, Factor J (1981) Studies on decapod crustacea from the Indian River region of Florida. XVIII. Rediscovery of Periclimenes (Periclimenes) pandionis Holthuis, 1951 (Caridea, Palaemonidae) with notes on the males and zoeal stages. Crustaceana 40:253-265

Goy J (1990) Components of reproductive effort and delay of larval metamorphosis in tropical marine shrimp (Crustacea:Decapoda: Caridea and Stenopodidea). PhD Thesis, Texas A\&M University, College Station

Grippa GB, d'Udekem d'Acoz C (1996) The genus Periclimenes Costa, 1844 in the Mediterranean Sea and the northeastern Atlantic Ocean: review of the species and description of Periclimenes sagittifer aegylios subsp. nov. (Crustacea, Decapoda, Caridea, Pontoniinae). Atti Soc It Sci Nat Mus Civ Nat Milano 135:401-412

Gurney R (1927) Larvae of the Crustacea Decapoda. Zoological results of the Cambridge Expedition to the Suez Canal. Trans Zool Soc Lond 22:231-286

Gurney R (1936) Notes on some decapod Crustacea of Bermuda. III-V. Proc Zool Soc Lond 1936:619-630

Gurney R (1938) The larve of the decapod Crustacea Palaemonidae and Alpheidae. Scient Rep Gt Barrier Reef Exped VI(I):1-60

Harms J (1992) Larval development and delayed metamorphosis in the hermit crab Clibanarius erythropus (Latreille) (Crustacea, Diogenidae). J Exp Mar Biol Ecol 156:151-160

Knowlton N, Keller BD (1986) Larvae which fall short of their potential: highly localized recruitment in an alpheid shrimp with extended larval development. Bull Mar Sci 39:213-223

Kurata H (1970) Studies on the life histories of decapod crustacea of Georgia. PhD Thesis, University of Georgia, Sapelo Island

Kurian C (1956) Larvae of decapod crustacea from the Adriatic Sea. Acta Adriat 6:1-108
Neumann V (1998) A review of the Maja squinado (Crustacea: Decapoda: Brachyura) species-complex with a key to the eastern Atlantic and Mediterranean species of the genus. J Nat Hist 32:1667-1684

Nizinski MS (1989) Ecological distribution, demography and behavioral observations on Periclimenes anthophilus, an atypical symbiotic cleaner shrimp. Bull Mar Sci 45:174-188

Paula J (1982) Sobre o desenvolvimento larvar planctónico dos crustáceos decápodes na costa portuguesa. Rel estágio. Faculdade de Ciências da Universidade de Lisboa, Portugal

Pohle G, Telford M (1981) The larval development of Dissodactylus crinitichelis Moreira, 1901 (Brachyura: Pinnotheridae) in laboratory culture. Bull Mar Sci 31:753-773

Reyne A (1949) Faure's vloeistof als Insluitmiddel voor Microscopische Prepataten van klein Insecten. Entomol Ber 13:37-42

Sarver D (1979) Larval culture of the shrimp Thor amboinensis (De Man, 1888) with reference to its symbiosis with the anemone Antheopsis papillosa (Kwietniwski, 1898). Crustaceana 5:176178

Strasser KM, Felder DL (1998) Settlement cues in successive development stages of the gosts shrimps Callichirus major and $C$. islagrande (Crustacea: Decapoda: Thalassinidae). Mar Biol 132:599-610

d'Udekem d'Acoz C (1996) Description of Periclimenes wirtzi sp. nov., a new pontoniine shrimp from Madeira and the Azores, with a checklist of Eastern Atlantic and Mediterranean Pontoniinae (Crustacea, Decapoda, Caridea) Bull Inst R Sci Nat Belg 66:133-149

d'Udekem d'Acoz C (1999) Inventaire et distribution des crustacés décapodes de l'Atlantique nord-oriental, de la Méditerranée et des eaux continentales adjacentes au nord de $25^{\circ} \mathrm{N}$. Patrimoines naturels (M.N.H.N./S.P.N.) 40:1-383 